\title{
Co (II), Ni (II) and Cu (II) Complexes with Schiff Base Ligand: Syntheses, Characterization, Antimicrobial Studies and Molecular Docking Studies
}

\author{
Arumugam AP ${ }^{1}$, Guhanathan $S^{2}$ and Elango $\mathbf{G}^{{ }^{*}}$ \\ ${ }^{1}$ Department of Chemistry, Govt Arts College, Tiruvannamalai, Tamil Nadu, India \\ ${ }^{2}$ PG \& Research Department of Chemistry, Muthurangam Government Arts College, Vellore-632002, Tamil Nadu, India
}

Received: September 04, 2017; Accepted: September 28, 2017; Published: October 03, 2017

*Corresponding author: Elango G, Department of Chemistry, Govt Arts College, Tiruvannamalai, Tamil Nadu, India. E-mail: profgelangogactvm@ gmail.com,sai_gugan@yahoo.com

\begin{abstract}
This paper is an analysis about the Schiff base ligands and its Co (II), Ni (II) and Cu (II) complexes. In the past few decades there has been an increased interest in this area. Synthesis of Schiff base can be done in many ways, but the most common method is the nucleophilic attack of primary amines on the carbon of aldehydes or ketones. The end result of this reaction is a compound in which $\mathrm{C}=0$ is replaced by a $\mathrm{C}=\mathrm{N}$. This study reported the synthesis of the new ligands, (E)-4-((5-benzoyl-2-((E)-(2-hydroxybenzylidine) amino) phenyl) amino) pentan-2-one. These Schiff base type ligands were respectively obtained by means of the reaction of Salicylaldehyde, 3, 4-diaminobenzophenone and acetyl acetone at molar ratio 1:1:1. The respective Co (II), Ni (II) and Cu (II) complexes were synthesized by the reaction of Ligand with metal nitrate hexa hydrate, at molar ratio 1:1. The chemical identification of ligands and respective complexes was established through spectroscopic data (FT-IR, UV-Vis, ${ }^{1} \mathrm{H}$ NMR and ${ }^{13} \mathrm{C}$ NMR). Macro cyclic complexes are non-electrolytic nature as their molar conductivities $(\Lambda \mathrm{M})$ in DMSO of $10^{-3} \mathrm{M}$ solution from the EPR study the complexes proposed to be octahedral geometry. The complexes have been tested against gram positive and gram negative bacteria using agar well diffusion method. It was found that compounds show different activity of inhibition on growth of the bacteria and finally the biological importance of the synthesized ligands are assessed by performing docking studies using Auto Dock VinaPyRx software.
\end{abstract}

Keywords: Schiff base; EPR study; Antimicrobial Activity; Docking study;

\section{Introduction}

Transition metals are metallic elements that have an incomplete $\mathrm{d}$ or $\mathrm{f}$ shells in the neutral or cationic states. These incomplete valance shell orbitals allow it to accept electrons from Lewis bases to form coordination complexes very easily compared to other group of elements. Ligands therefore must be a Lewis base. They must contain at least one pair of non-bonding electrons that can be donated to a metal ion. The Schiff base is named after Hugo Schiff and is a compound with a functional group that contains a $\mathrm{C}-\mathrm{N}$ double bond with the nitrogen connected to an aryl or alkyl group. Schiff bases in a broad sense have the general formula $\mathrm{R}^{1} \mathrm{R}^{2} \mathrm{C}=\mathrm{NR}^{3}$, where $\mathrm{R}$ is an organic side chain. Schiff base is synonymous with azomethine and may also be referred to as imines.

Recently, Schiff bases are used as intermediates for the synthesis of amino acids or as ligands for preparation of metal complexes having a series of different structures [1]. Schiff base compounds and their metal complexes are very important as catalysts in various biological systems, polymers, dyes and medicinal and pharmaceutical fields [2,3] they comprise miscellaneous therapeutically potent applications in the field of medicinal chemistry [4].Their use in birth control, food packages and as an $\mathrm{O}_{2}$ de-tector is also outlined [3]. They have been shown to exhibit a broad range of biological activities, including antifungal, antibacterial, an-timalarial, anti-inflammatory, antiviral, and antipyretic properties $[5,6]$.

A variety of Schiff's base and its complexes have been studied extensively. Several mo $\neg$ del systems, including those with bidentate, tridentate, tetradentate, multidentate Schiff base ligands, and their coordination chemistry of cobalt (II), Nickel (II) and copper (II) attracts much attention because of its biological relevance and its own interesting coordination chemistry such as geometry, flexible redox property. In this paper to discuss the synthesis, spectroscopic and antimicrobial studies of Schiff's base and its cobalt (II), nickel (II) and copper (II) complexes. The structures of the compounds are characterized by using IR, UV, NMR, ESI mass and EPR spectroscopic techniques.

\section{Experimental}

All the chemicals used were of analytic grade, and were purchased from Sigma-Aldrich. Metal salt were purchased from E. Merck and were used as received. All solvents used were of standard/spectroscopic grade.

\section{Synthesis of Ligand (L)}

Ligand (L) was synthesized by refluxing a hot ethanolic 
solution of Acetyl acetone, Salicylaldehyde. They were mixed slowly with constant stirring. To the above mixture was added an ethanolic solution of 3, 4-diaminobenzophenone. Their molar ratio is $1: 1: 1$ temperature was maintained at $70^{\circ} \mathrm{C}$ for $2.30 \mathrm{~h}$ in the presence of Concentrated $\mathrm{HCl}$. On cooling the content overnight at $0^{\circ} \mathrm{C}$ an off white crystalline compound was separated out. This was filtered, washed several times with ethanol and dried in a vacuum desiccator over anhydrous calcium chloride. Yield $62 \%$, m.pt. $238^{\circ} \mathrm{C}$.

\section{Synthesis of complex}

Hot ethanolic solution of ligand and hot ethanolic solution of a given metal salt (cobalt nitrate, nickel nitrate and copper nitrate hexa hydrate) in 1:1 molar ratio were mixed together with constant stirring. The reaction mixture was refluxed at $70^{\circ} \mathrm{C}$ for $2.30 \mathrm{~h}$. The volume of the reaction mixture was reduced to 20 $25 \%$. The precipitate that formed was filtered off and washed with ethanol and dried under vacuum over anhydrous $\mathrm{CaCl}_{2}$ These are insoluble in water, chloroform, carbon tetrachloride, acetonitrile and partially soluble in ether, alcohol but freely soluble in DMF and DMSO.

\section{Physical methods}

The infrared spectrum was recorded using $\mathrm{KBr}$ pellets in the range 4400-400 $\mathrm{cm} 1$. UV-Visible spectra of the ligand and the complexes were recorded on Perkin Elmer Lambda 3B UVVisible Spectrophotometer in the range $200-900 \mathrm{~nm}$. The molar conductance of the ligand and the complexes were measured using 10-3M solution of DMSO at $25^{\circ} \mathrm{C}$ using an Elico CM-180 Conductivity meter and Elico type CC-03 Conductivity cell of cell constant $1.05 \mathrm{~cm}^{-1}$.The ${ }^{1} \mathrm{H} \&{ }^{13} \mathrm{C}$ NMR spectra of the ligand and complex was recorded in Joel $500 \mathrm{MHz}$ NMR spectrometer using $\left(\mathrm{CD}_{3}\right)_{2} \mathrm{SO}$. The mass spectra of the complexes were recorded by JEOL GC mate Mass Spectrophotometer. Magnetic susceptibility was measured at room temperature on a Gouy balance using $\mathrm{CuSO}_{4} \cdot 5 \mathrm{H}_{2} \mathrm{O}$ as a callibrant. The EPR spectra of the complex were recorded as crystalline sample and in the solution of DMF at room temperature on JEX-X3 Series of a system using the DPPH as the g-marker. Antimicrobial activity was tested by using agar well diffusion method and molecular docking studies were record using Auto Dock VinaPyRx software.

\section{Result and discussion}

\section{Ligand}

The purity of the ligand (L) $98.62 \%$ has been checked by HPLC. The ESI-mass spectrum (Figure 2) of the ligand (L) shows a parental ion peak $(\mathrm{M}+) \mathrm{m} / \mathrm{z}=398$. The spectrum exhibit a peak at $\mathrm{m} / \mathrm{z}=356$ is due to $\mathrm{C}_{23} \mathrm{H}_{20} \mathrm{~N}_{2} \mathrm{O}_{2}$ caution. A peak with high intensity is present at $\mathrm{m} / \mathrm{z}=315(85 \%)$ is due to base peak. This peak is corresponding to cationic species with three aromatic rings. The other peaks at $271,237,220,179,157,119,96,82$ and 59 are corresponding to other fragments.

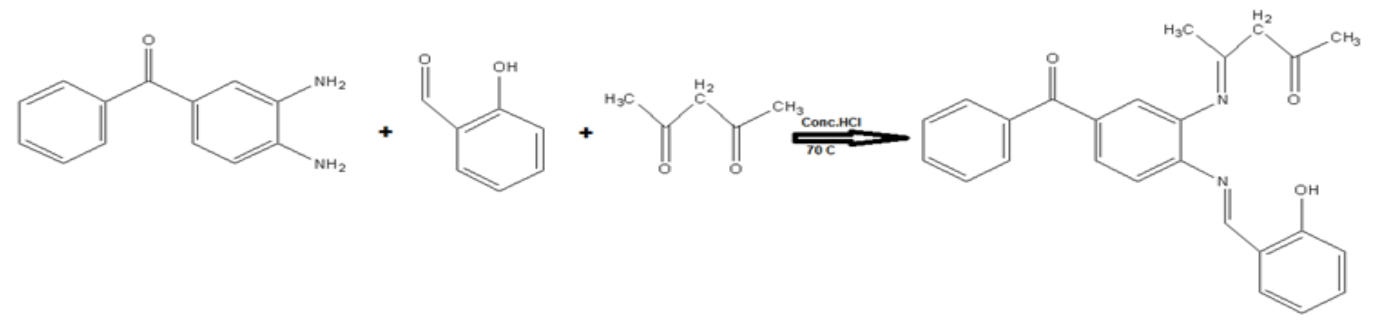

Figure 1: Proposed structure of Ligand

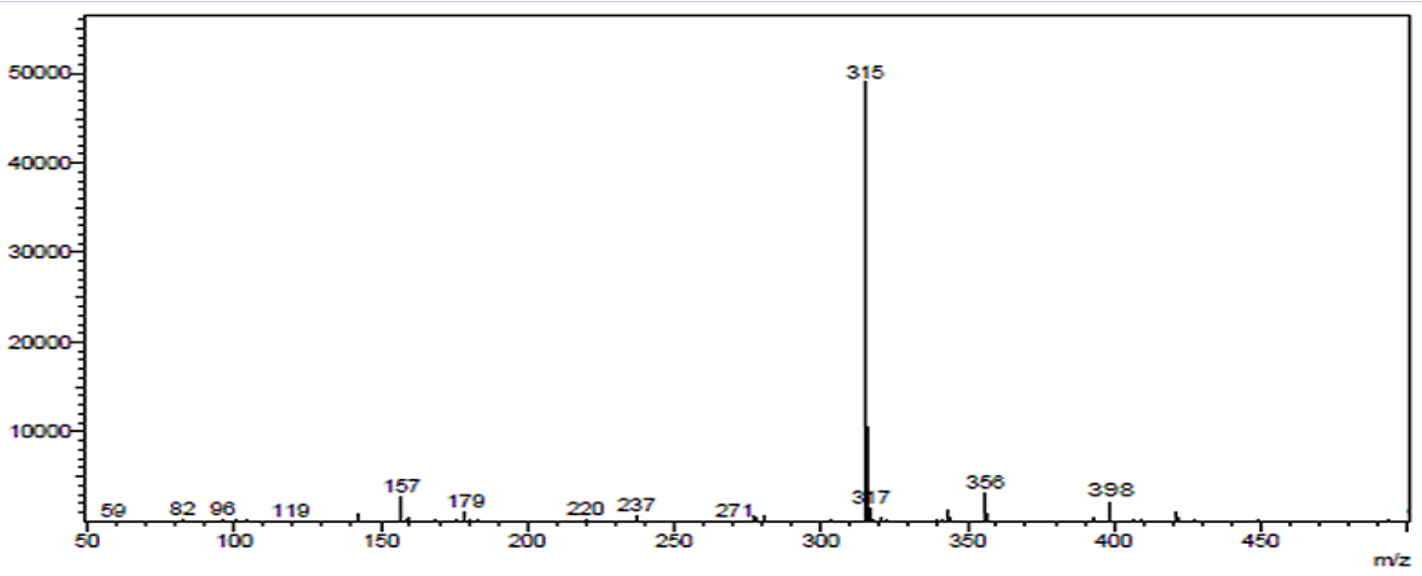

Figure 2: ESI Mass spectrum of Ligand (L) 
The FTIR spectrum of the ligand (Figure 3) shows at $1607 \mathrm{~cm}^{-1}$ corresponding to the $v(\mathrm{C}=\mathrm{N})$ stretching vibration and $3291 \mathrm{~cm}^{-1}$ phenolic hydroxyl group. IR spectra of the ligand showed band at $1287 \mathrm{~cm}^{-1}$ which is ascribed to the stretching vibration of the phenolic aromatic oxygen [7]. The bands at $2671 \mathrm{~cm}^{-1}$ and 3070 $\mathrm{cm}^{-1}$ are corresponding to $\mathrm{C}-\mathrm{H}$ stretching of aromatic ring [8].

The electronic spectrum of the Schiff base ligand (Figure 4) shows mainly two absorption bands at 252 and $345 \mathrm{~nm}$. The first band arise from $\pi-\pi^{*}$ transition with the azomethine chromospheres [7].The second band at $350 \mathrm{~nm}$ is due to the $n-\pi^{*}$ transition which is overlapping with the intermolecular CT from the phenyl ring to the azomethine group. On the complexation the absorption bands undergo a bathochromic shift compared to the free ligand as a result of coordination via the nitrogen atoms of the azomethine group.

In the $1 \mathrm{H}$ NMR spectrum of ligand (Figure 5) exhibit signals at $2.50 \mathrm{ppm}$ due to $\mathrm{CH}_{2}-\mathrm{CN}, 3.39 \mathrm{ppm}$ due to $-\mathrm{CO}-\mathrm{CH}_{2}, 2.11 \mathrm{ppm}$ due to $\mathrm{CH}_{3}-\mathrm{C},[8] 8.10 \mathrm{ppm}$ due to $\mathrm{Ar}-\mathrm{CH}=\mathrm{N}$ [9]A sharp multiplet signals7.03 - $7.81 \mathrm{ppm}$ due to Ar-H. A singlet corresponding to one proton observed at $12.80 \mathrm{ppm}$ is due to Ar-OH. As well as in the ${ }^{13} \mathrm{C}$ NMR spectrum of ligand (Figure 6) indicated new resonance are $19.05\left(\mathrm{C}-\mathrm{CH}_{3}\right), 56\left(\mathrm{C}-\mathrm{CH}_{2}-\mathrm{CO}\right), 113-138(\mathrm{C}=\mathrm{C})$, 158.45(C=N), 195.95(Ph-CO-Ph) [14].

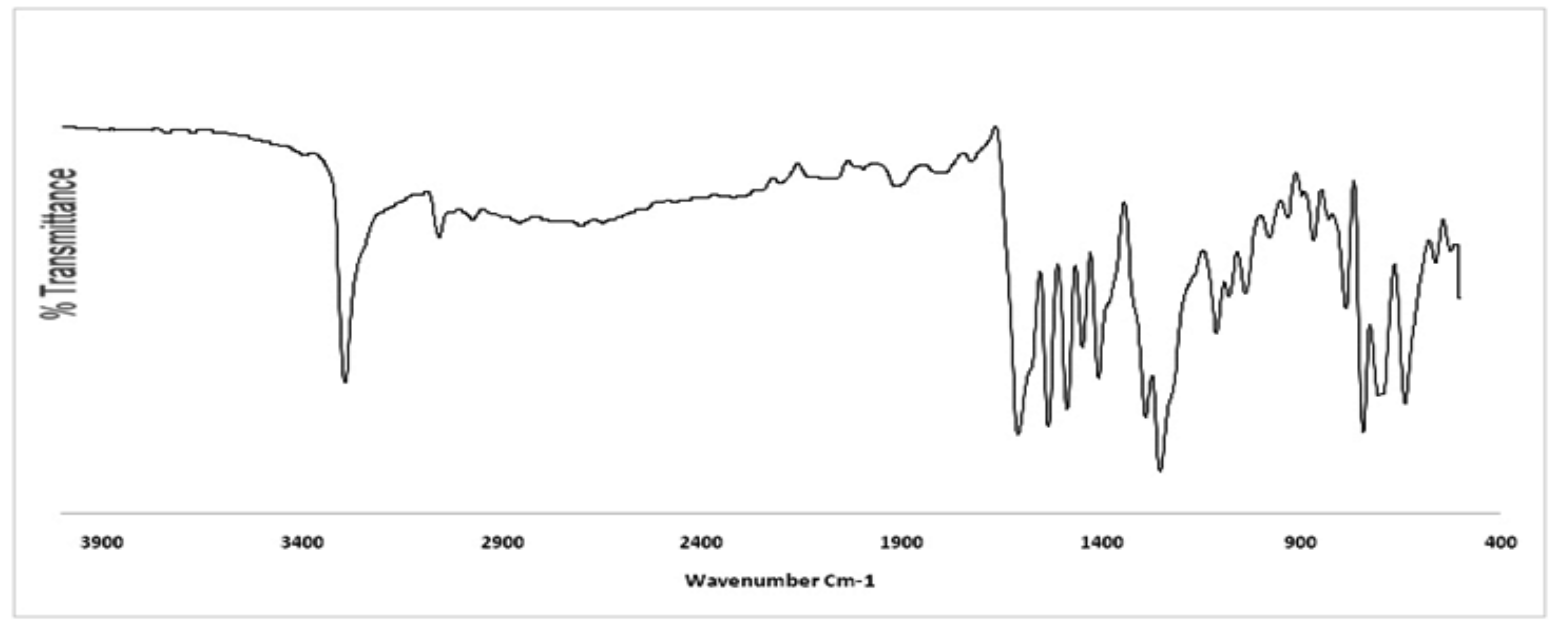

Figure 3: IR spectrum of Ligand (L)

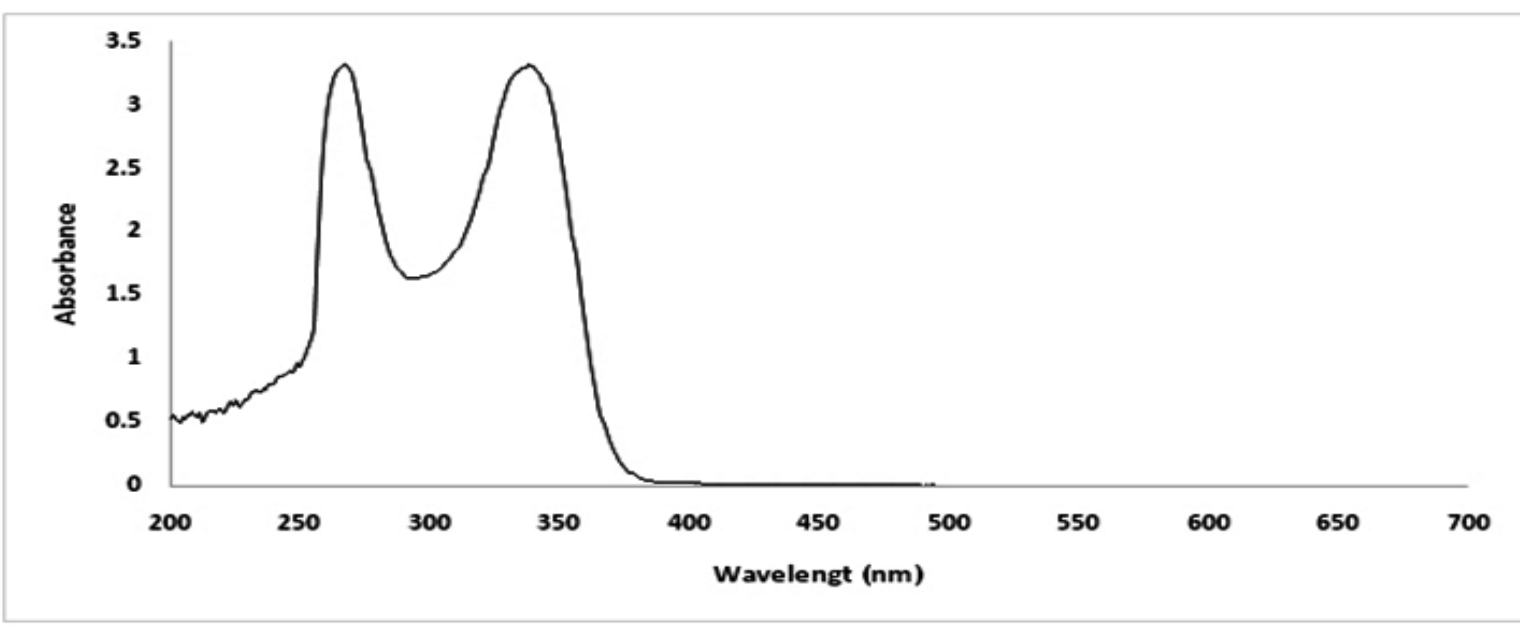

Figure 4: Electronic spectrum of Ligand (L) 
Palani-21

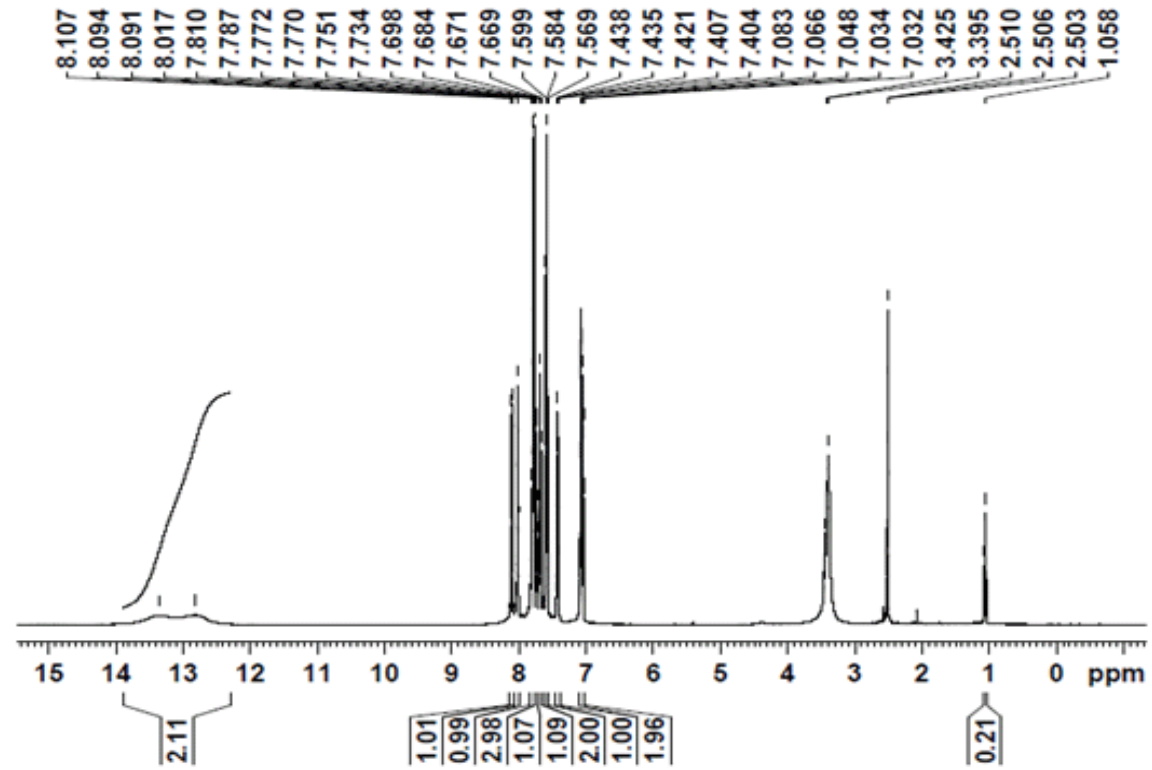

\section{(6) SRM \\ UNIVERSITY}

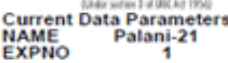

EXPNO $\quad 1$

F2. Acquisition Parameters
Date- 20170303

$\begin{array}{lc}20170303 \\ \text { Time- } & 19.12\end{array}$

PROBHD $5 \mathrm{~mm}$ PABBO BB/

$\begin{array}{ll}\text { TD } & \\ \text { SOLVENT } & 65536 \\ \text { DMSO }\end{array}$

IS

$\quad 10000.000 \mathrm{~Hz}$
$0.152588 \mathrm{~Hz}$
FIDRES
$32767999 \mathrm{sec}$

$\begin{array}{ll}\text { AQ } & 3.2767999 \mathrm{sec} \\ \text { RG } & 62.01\end{array}$

$\begin{array}{ll}\mathrm{RG} & 62.01 \\ \mathrm{DW} & 50.000 \mathrm{usec}\end{array}$

$\begin{array}{ll}\text { TE } & 2940 \mathrm{~K} \\ \mathrm{TE} & \mathbf{2 9 0 \mathrm { K }} \\ \mathrm{D} 1 & \mathbf{0 0 0 0 0 0 0 0 \mathrm { sec }}\end{array}$

$\mathrm{D} 0$

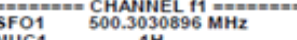

N1 11.50 usec

PLW1 $18.00000000 \mathrm{~W}$

F2 - Processing parameters

SF $\quad 500.3000000 \mathrm{MHz}$

WDW 0 EM

LB $0.30 \mathrm{~Hz}$

1.00

Figure 5: ${ }^{1} \mathrm{H}$ NMR spectrum of ligand (L)

Palani-21

๘

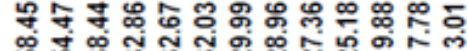
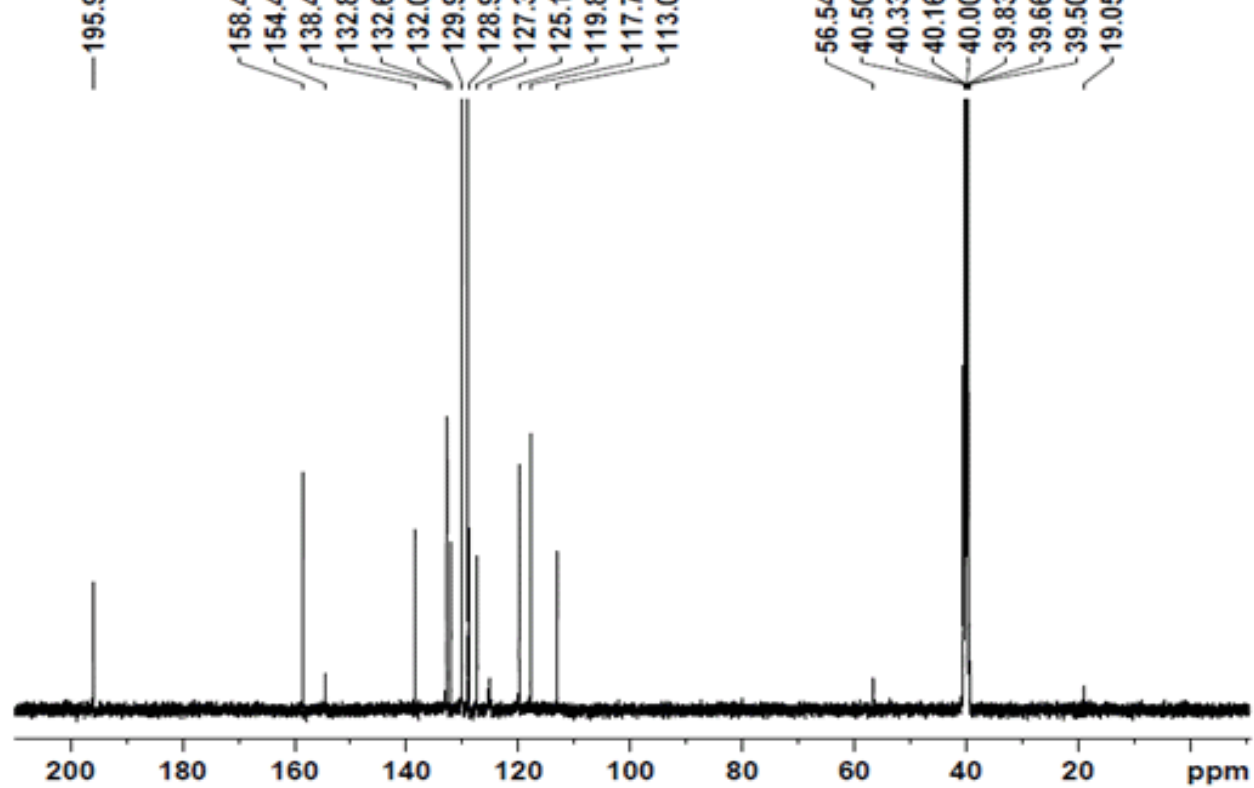

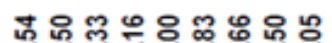

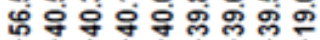

(9) SRM

UNIEASITY

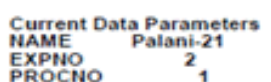

F2 - Acquisition Parameters

F2 - Acquisition Param
Date_ 20170303

insTRUM PROBHD $5 \mathrm{~mm}$ PABE

PULPROG $\mathrm{zgpg} 30$

TDLLVENT ${ }^{65536}$ DMSO

NS 102

$\begin{array}{ll}\text { DS } & 4 \\ \text { SWH } & 29761.904 \mathrm{~Hz} \\ \text { FIDRES } & 0.454131 \mathrm{~Hz}\end{array}$

PQ $1.1010048 \mathrm{sec}$

$\begin{array}{ll}\text { RG } & 186.93 \\ \text { DW } & 16.800 \text { usec }\end{array}$

$\begin{array}{ll}\text { DW } & 16.800 \mathrm{usec} \\ \text { DE } & 6.50 \mathrm{usec}\end{array}$

$\begin{array}{ll}2.00000000 & \mathrm{sec} \\ \mathrm{D} & \end{array}$

SFO1 $125.8131145 \mathrm{MHz}$

$\begin{array}{ll}\text { SFO1 } & 125.8131145 \mathrm{MH} \\ \text { NUC1 } & 13 \mathrm{C}\end{array}$

$\begin{array}{lc}\text { NuC1 } & 13 \mathrm{C} \\ \text { P1 } & 9.73 \mathrm{usec} \\ \text { PLw1 } & 76.00000000 \mathrm{~W}\end{array}$

SFO2 $500.3020012 \mathrm{MHz}$

SFO2 $500.3020012 \mathrm{MHz}$

CPDPRGI2 waltz16

80.00 usec

$\begin{array}{ll}\text { PLW2 } & 18.00000000 \mathrm{~W} \\ \text { PLW12 } & 0.37195000 \mathrm{~W}\end{array}$

LW13 0.18708999 W F2 - Processing parameters
SI
SF $127688^{2}$
WDW 125005314
EM EM $\mathrm{M}$

Figure 6: ${ }^{13} \mathrm{C}$ NMR spectrum of ligand (L) 


\section{Metal Complexes}

On the basis of molar conductance measurements (Table 1) of the complexes in DMSO corresponds to be non-electrolytic nature of the complexes. Thus the complexes may be formulated as [M
(L) $\left.\left(\mathrm{NO}_{3}\right)_{-2}\right]$.xH2O where $\mathrm{M}=\mathrm{Co}(\mathrm{II}), \mathrm{Ni}(\mathrm{II})$ and $\mathrm{Cu}(\mathrm{II})$ and $\mathrm{L}$ is (E)-4((5-benzoyl-2-((E)-(2-hydroxybenzylidine)amino)phenyl)imino) pentan-2-one.

Table 1: Molar conductance and Electronic Spectroscopic Data of the Schiff Base Ligand and its metal complex

\begin{tabular}{|c|c|c|c|c|c|}
\hline Compound & $\begin{array}{c}\text { Molar conductance } \\
\Omega^{-1} \mathbf{c m}^{2} \mathbf{m o l}^{-1}\end{array}$ & Colour & $\mathrm{M} . \mathrm{P}\left({ }^{\circ} \mathrm{C}\right)$ & Yield (\%) & $\Lambda \max (\mathbf{n m})$ \\
\hline Ligand(L) & - & $\begin{array}{c}\text { Off } \\
\text { white }\end{array}$ & 237 & 68 & 252,345 \\
\hline$\left[\mathrm{Co}(\mathrm{L})\left(\mathrm{NO}_{3}\right)_{2}\right] \cdot \mathrm{xH}_{2} \mathrm{O}$ & 16.23 & Brown & $>300$ & 48 & $268,345,437,514,776$ \\
\hline$\left[\mathrm{Ni}(\mathrm{L})\left(\mathrm{NO}_{3}\right)_{2}\right] \cdot \mathrm{xH}_{2} \mathrm{O}$ & 9.80 & $\begin{array}{c}\text { Brown } \\
\text { black }\end{array}$ & $>300$ & 45 & $258,335,437,550,776$ \\
\hline$\left[\mathrm{Cu}(\mathrm{L})\left(\mathrm{NO}_{3}\right)_{2}\right] \cdot \mathrm{xH}_{2} \mathrm{O}$ & 10.54 & $\begin{array}{c}\text { Dark } \\
\text { brown }\end{array}$ & 294 & 50 & $285,367,431,660,730$ \\
\hline
\end{tabular}

\section{Infra-red spectral bands due to anion}

A comparative study of the FTIR spectra of ligand and its metal complexes discloses that some peaks are common and therefore, only important peaks, which have either shifted or have newly appeared, are discussed. (Table 2) shows that $v(\mathrm{C}-0)$ and $v(\mathrm{C}=\mathrm{N})$ modes appear at $1287-1327 \mathrm{~cm}^{-1}$ and $1607-1618 \mathrm{~cm}^{-1}$ respectively. The shifting of (C-0) to higher frequency as compared to the ligand $\left(1287 \mathrm{~cm}^{-1}\right)$ is owing to the conversion of hydrogen bonded structure into a covalent metal bonded structure. Metalligand bond is further confirmed by the appearance of a medium intensity band in the range $474-478$ and $522-536 \mathrm{~cm}^{-1}$ in the spectra of the complexes allotted to stretching frequencies of (M$\mathrm{N})$ bond and (M-O) bond formation respectively [10]IR spectra of the nitrate complexes (Figure $7(\mathrm{a}-\mathrm{c})$ ), display three medium intensity bands due to (N-O) stretching in the region $~ 1382-1384$ $\mathrm{cm}^{-1}$, suggesting that both the nitrate groups are coordinated to the central metal ion [11].
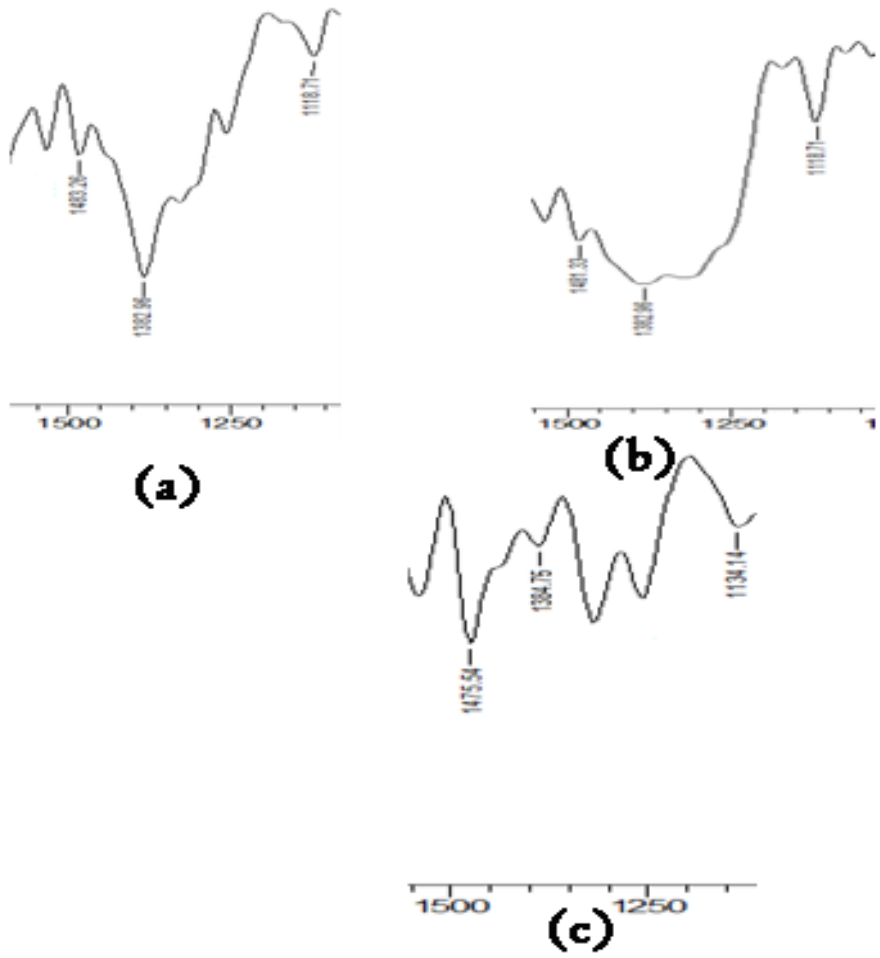

Figure 7: IR spectral bands of anions (a) $\left[\mathrm{Co}(\mathrm{L})\left(\mathrm{NO}_{3}\right)_{2}\right] \cdot \mathrm{xH}_{2} \mathrm{O}$; (b) $\left[\mathrm{Ni}(\mathrm{L})\left(\mathrm{NO}_{3}\right)_{2}\right] \cdot \mathrm{xH}_{2} \mathrm{O}$; (c) $\left[\mathrm{Cu}(\mathrm{L})\left(\mathrm{NO}_{3}\right)_{2}\right] \cdot \mathrm{xH}_{2} \mathrm{O}$ 
Table 2: Infrared Spectroscopic Data of the Schiff Base Ligand and its metal complex

\begin{tabular}{|c|c|c|c|c|}
\hline Compound & $\boldsymbol{v}(\boldsymbol{C}=\boldsymbol{N})$ & $\boldsymbol{v}(\boldsymbol{C}-\boldsymbol{O})$ & $\boldsymbol{v}(\boldsymbol{M}-\boldsymbol{N})$ & Ionic nitrate $(\boldsymbol{M}-\boldsymbol{O})$ \\
\hline Ligand(L) & 1607 & 1287 & - & - \\
\hline$\left[\mathrm{Co}(\mathrm{L})\left(\mathrm{NO}_{3}\right)_{2}\right] \cdot \mathrm{xH}_{2} \mathrm{O}$ & 1616 & 1327 & 476 & 536 \\
\hline$\left[\mathrm{Ni}(\mathrm{L})\left(\mathrm{NO}_{3}\right)_{2}\right] \cdot \mathrm{xH}_{2} \mathrm{O}$ & 1618 & 1323 & 478 & 534 \\
\hline$\left[\mathrm{Cu}(\mathrm{L})\left(\mathrm{NO}_{3}\right)_{2}\right] \cdot \mathrm{xH}_{2} \mathrm{O}$ & 1610 & 1317 & 474 & 522 \\
\hline
\end{tabular}

\section{Cobalt (II) complex}

The magnetic moment measurement of the cobalt (II) complex at room temperature lies in the range $4.98-5.01$ B.M. The electronic spectrum of Co (II) complex show three bands (Figure 8). These bands may be assigned to ${ }^{4} \mathrm{~T}_{1} \mathrm{~g} \rightarrow{ }^{4} \mathrm{~T}_{2} \mathrm{~g}(\mathrm{~F})\left(v_{1}\right)$ ${ }^{4} \mathrm{~T}, \mathrm{~g} \rightarrow{ }^{4} \mathrm{~A}_{2} \mathrm{~g}(\mathrm{~F})\left(\mathrm{v}_{2}\right)$ and ${ }^{4} \mathrm{~T}_{1} \mathrm{~g} \rightarrow{ }^{4} \mathrm{~T}_{1} \mathrm{~g}(\mathrm{P})\left(\mathrm{v}_{3}\right)$ transitions, respectively $[12,13]$. In the $1 \mathrm{H}$ NMR spectrum of cobalt (II) complex (Figure
9) exhibit A sharp multiplet signals 7.09 - $7.76 \mathrm{ppm}$ due to Ar-H. A singlet corresponding to one proton observed at 12.00-13.00 ppm is due to Ar-OH. [8, 9] As well as the13C NMR spectrum (Figure10) agree with the expected absorptions indicated new resonance are $47.86\left(\mathrm{C}-\mathrm{CH}_{2}-\mathrm{CO}\right), 113-138(\mathrm{C}=\mathrm{C}), 159.00(\mathrm{C}=\mathrm{N})$, 195.64(Ph-CO-Ph) [14].

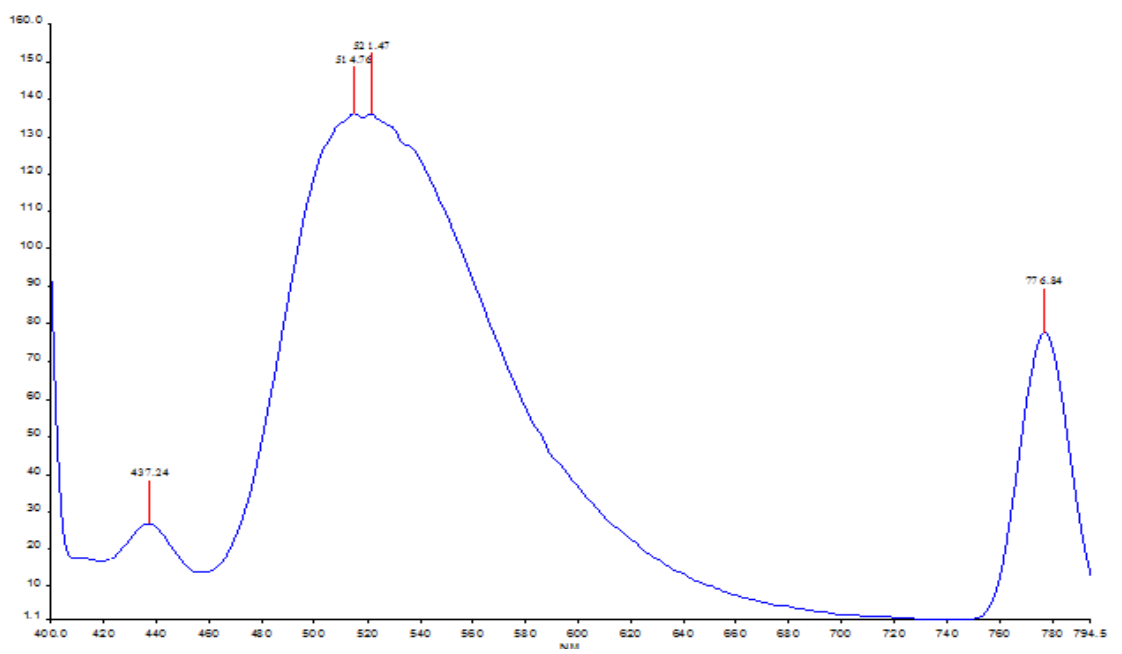

Figure 8: Electronic spectrum of Co (II) complex
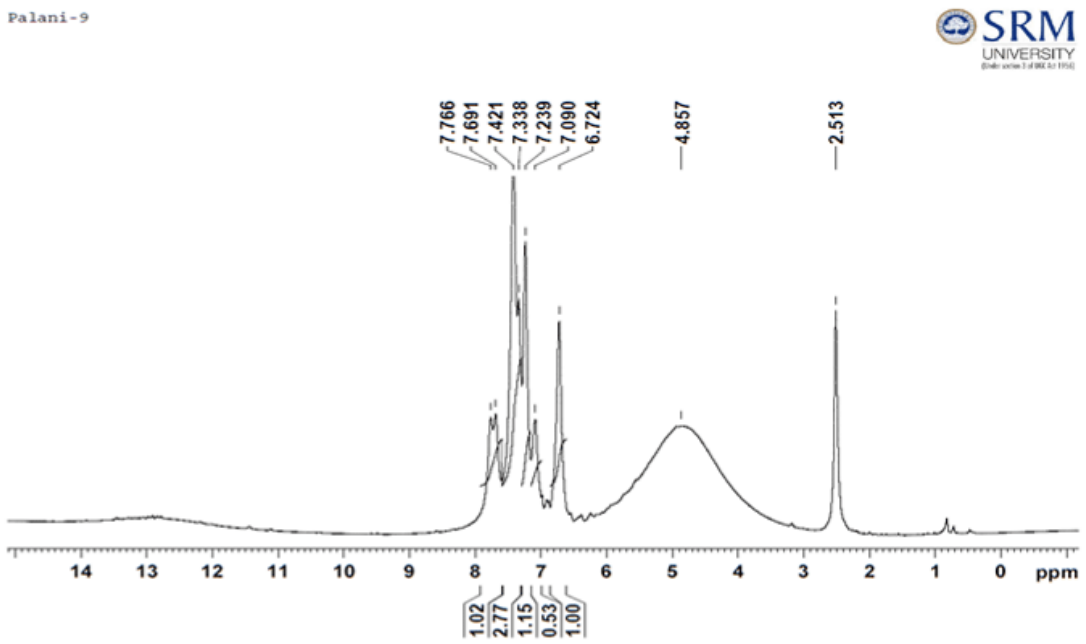

Figure 9: ${ }^{1} \mathrm{H}$ NMR spectrum of Cobalt (II) Complex 
Palani-9
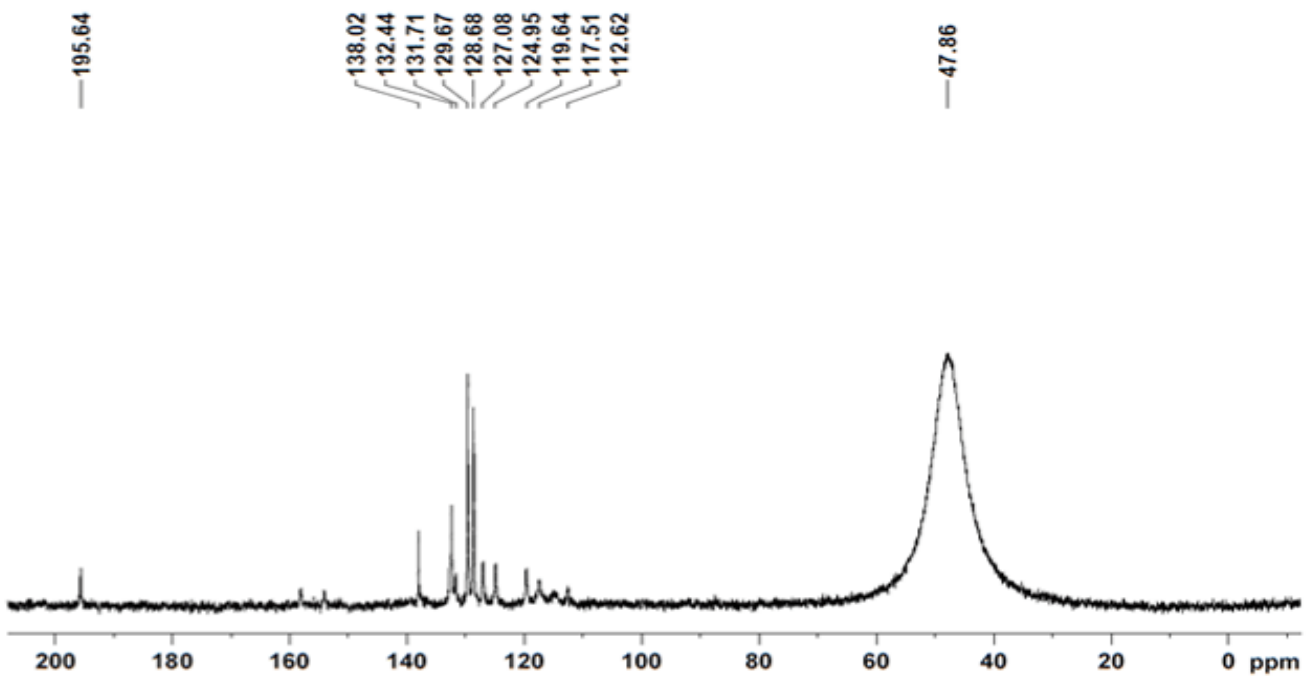

Figure 10: ${ }^{13} \mathrm{CNMR}$ spectrum of Cobalt (II) Complex

\section{Nickel (II) complex}

The magnetic moment of the $\mathrm{Ni}(\mathrm{II})$ complex at room temperature lie in the range 2.96-2.98 B.M.[15]These values show the presence of octahedral configuration. These complex display three electronic spectral bands (Figure 11) at 776, 570 and 437nm assignable to ${ }^{3} \mathrm{~A}_{2} \mathrm{~g} \rightarrow{ }^{3} \mathrm{~T}{ }_{2} \mathrm{~g}(\mathrm{~F})\left(\mathrm{v}_{1}\right),{ }^{3} \mathrm{~A}_{2} \mathrm{~g} \rightarrow 3 \mathrm{~T} \mathrm{~T}_{1} \mathrm{~g}(\mathrm{~F})\left(\mathrm{v}_{2}\right)$ and ${ }^{3} \mathrm{~A}_{2} \mathrm{~g} \rightarrow{ }^{3} \mathrm{~T}_{1} \mathrm{~g}(\mathrm{P})\left(v_{3}\right)$ transitions, respectively. These bands indicate that the complex have also confirm an octahedral geometry and might possess $\mathrm{D}_{4 \mathrm{~h}}$ symmetry [12].The $1 \mathrm{H}$ NMR and ${ }^{13} \mathrm{C}$ NMR spectrum shown in the (figure12,13). These signals also confirm the hydrogen and the Carbon environment of the complex.

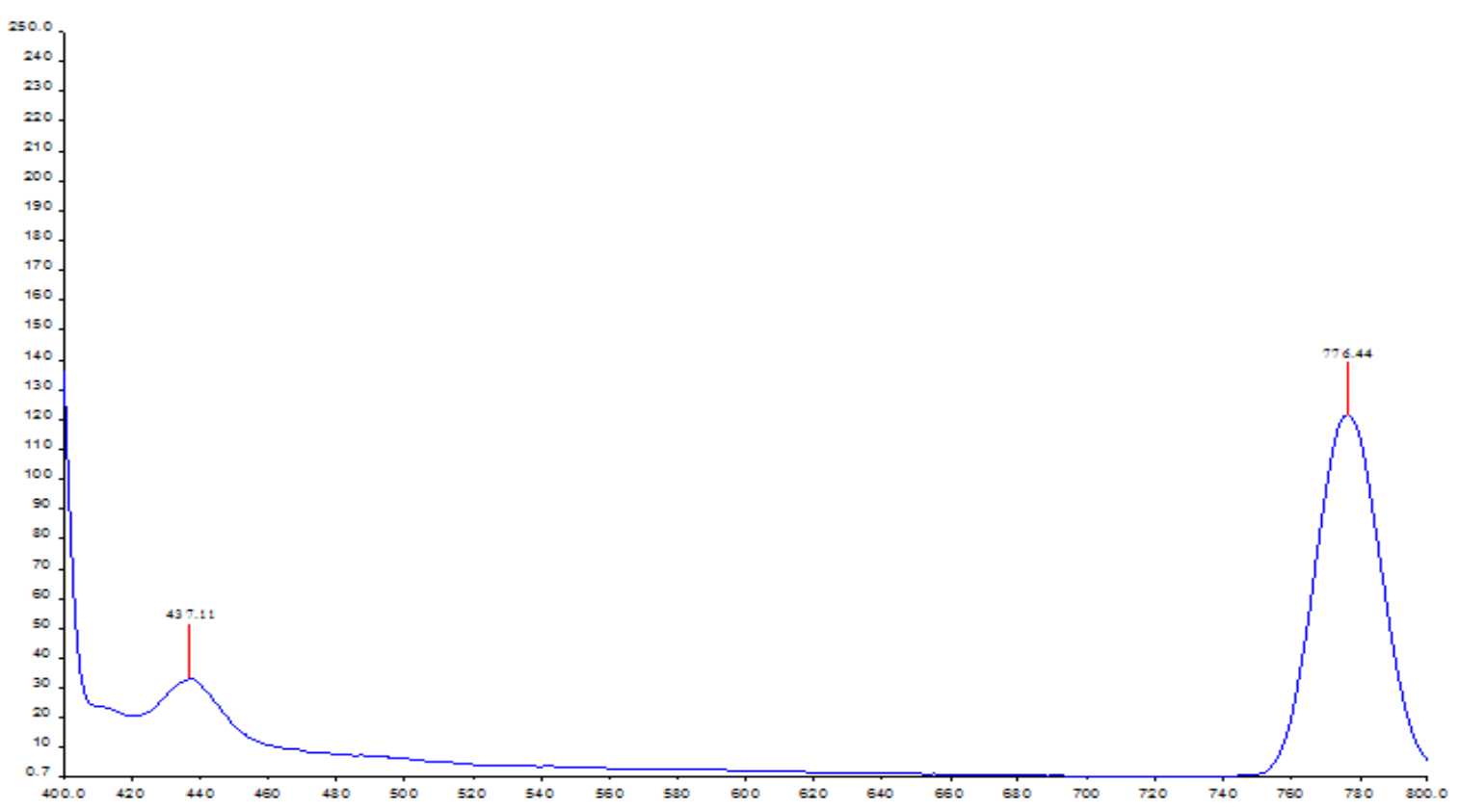

Figure 11: Electronic spectrum of Ni (II) complex 
Co (II), Ni (II) and Cu (II) Complexes with Schiff Base Ligand: Syntheses, Characterization, Antimicrobial Studies and Molecular Docking Studies

\begin{tabular}{|c|c|c|c|c|c|c|c|c|c|c|c|c|}
\hline \multirow[t]{2}{*}{ Microorganism } & \multicolumn{3}{|c|}{ Escherichia coli } & \multicolumn{3}{|c|}{ Staphylococcus } & \multicolumn{3}{|c|}{ Enterococci } & \multicolumn{3}{|c|}{ Pseudomonas } \\
\hline & 25 & 50 & 100 & 25 & 50 & 100 & 25 & 50 & 100 & 25 & 50 & 100 \\
\hline Ligand(L) & - & $5 \mathrm{~mm}$ & $9 \mathrm{~mm}$ & $8 \mathrm{~mm}$ & $10 \mathrm{~mm}$ & $11 \mathrm{~mm}$ & $4 \mathrm{~mm}$ & $7 \mathrm{~mm}$ & $13 \mathrm{~mm}$ & - & - & - \\
\hline$\left[\mathrm{Co}(\mathrm{L})\left(\mathrm{NO}_{3}\right)_{2}\right] \cdot \mathrm{xH}_{2} \mathrm{O}$ & - & $8 \mathrm{~mm}$ & $10 \mathrm{~mm}$ & - & - & - & $5 \mathrm{~mm}$ & $7 \mathrm{~mm}$ & $9 \mathrm{~mm}$ & - & $4 \mathrm{~mm}$ & $9 \mathrm{~mm}$ \\
\hline$\left[\mathrm{Ni}(\mathrm{L})\left(\mathrm{NO}_{3}\right)_{2}\right] \cdot \mathrm{xH}_{2} \mathrm{O}$ & - & $5 \mathrm{~mm}$ & $8 \mathrm{~mm}$ & $6 \mathrm{~mm}$ & $8 \mathrm{~mm}$ & $10 \mathrm{~mm}$ & $7 \mathrm{~mm}$ & $9 \mathrm{~mm}$ & $12 \mathrm{~mm}$ & - & - & $7 \mathrm{~mm}$ \\
\hline$\left[\mathrm{Cu}(\mathrm{L})\left(\mathrm{NO}_{3}\right)_{2}\right] \cdot \mathrm{xH}_{2} \mathrm{O}$ & - & - & - & - & - & - & - & - & $5 \mathrm{~mm}$ & - & - & $4 \mathrm{~mm}$ \\
\hline
\end{tabular}

\begin{tabular}{|c|c|}
\hline Ligand/Complex & Binding Affinity (kcal/mol) \\
\hline Ligand & -7.9 \\
\hline Copper (II) complex & -9.0 \\
\hline Nickel (II) complex & -9.5 \\
\hline
\end{tabular}

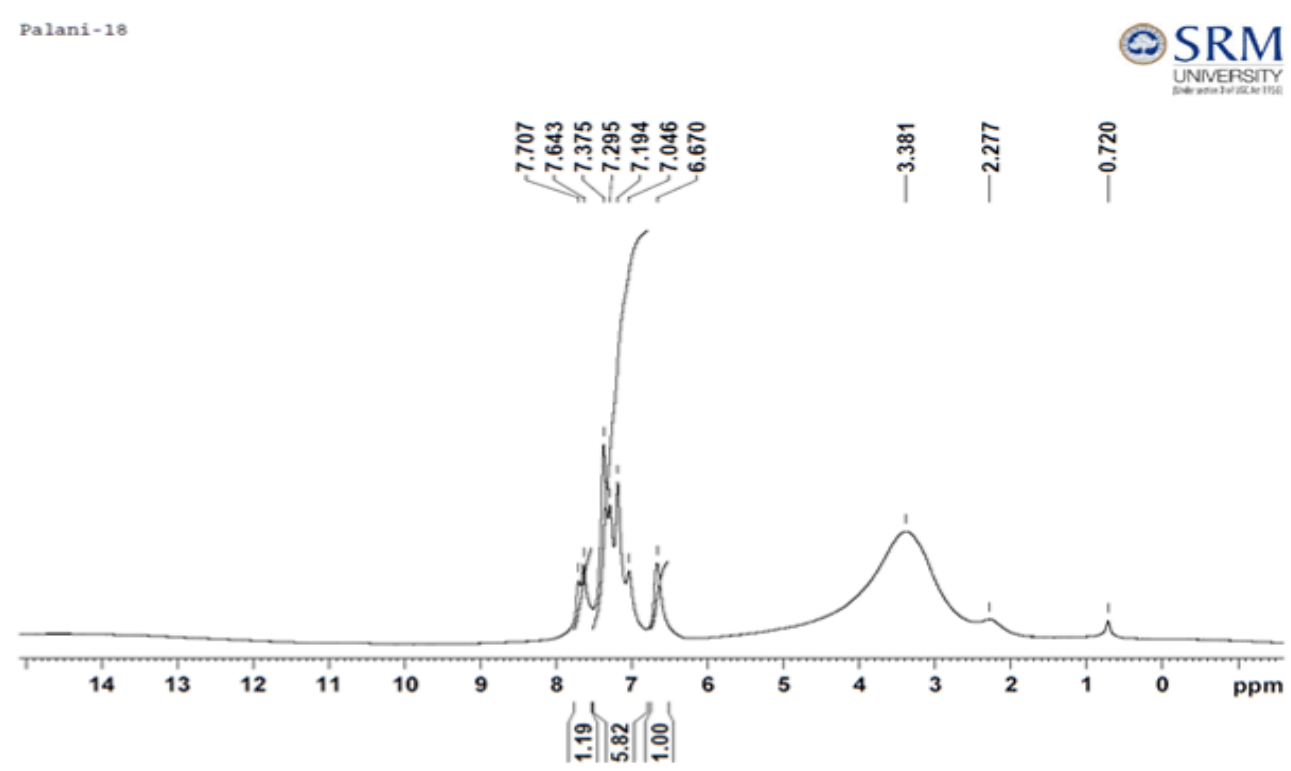

Figure 12: ${ }^{1} \mathrm{H}$ NMR spectrum of Cobalt (II) Complex

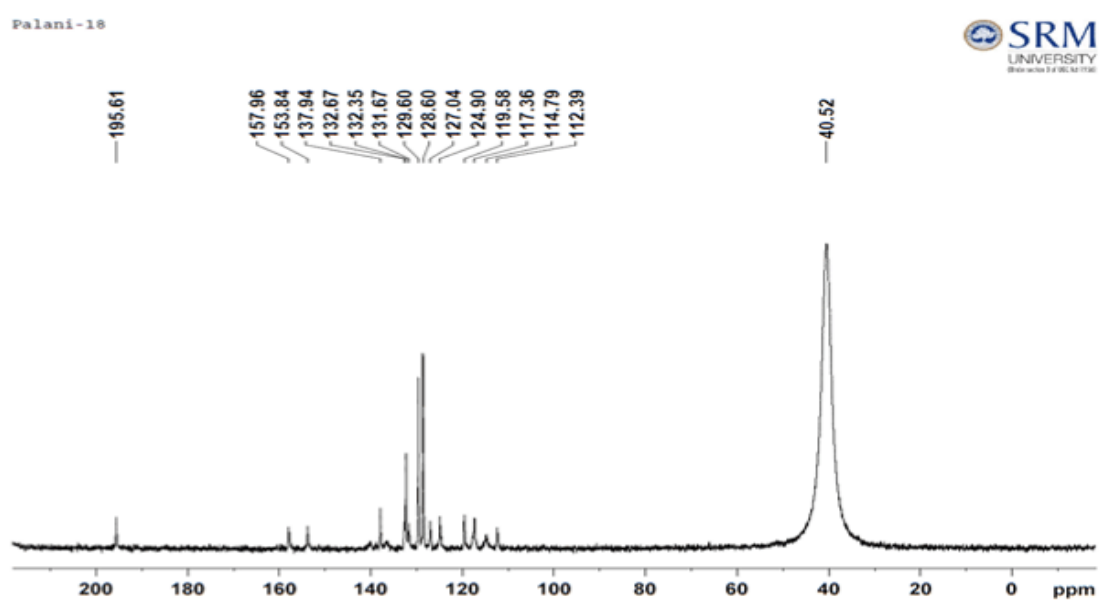

Figure 13: ${ }^{13} \mathrm{C}$ NMR spectrum of Cobalt (II) Complex 


\section{Copper (II) complex}

The magnetic moment measurement of the copper(II) complex at room temperature lie in the range $1.83-1.85$ B.M. $[16,17]$ Three spin allowed transition may be expected in the visible region and the Eg and $\mathrm{T}_{2 \mathrm{~g}}$ levels of $2 \mathrm{D}$ free ion will split into $B_{1 g}, A_{1 g}, B_{2 g}$ and $E_{g}$ levels respectively. Electronic spectrum (Figure14) of six coordinated copper complex display band at 730,660 and $431 \mathrm{~nm}$ corresponding to the following transitions
${ }^{2} \mathrm{~B}_{1} \mathrm{~g} \rightarrow{ }^{2} \mathrm{~B}_{2} \mathrm{~g} ;{ }^{2} \mathrm{~B}_{1} \mathrm{~g} \rightarrow{ }^{2} \mathrm{Eg}$ and ${ }^{2} \mathrm{~B}_{1} \mathrm{~g} \rightarrow{ }^{2} \mathrm{~A}_{1} \mathrm{~g}$. The EPR spectrum of $\mathrm{Cu}$ (II) complex (Figure15) is recorded at room temperature in DMF solution, lie in the range 2.0204-2.01142. The trend $g \|>\mathrm{g} \perp$ $>2.0023$ observed for the complex indicates that the unpaired electron is localized in the $\mathrm{dx} \mathrm{dx}^{2}-\mathrm{y}^{2}$ orbital of the $\mathrm{Cu}$ (II) ion and is characteristic for the axial symmetry. The shape of the ESR line indicates that the present complex has distorted octahedral complex

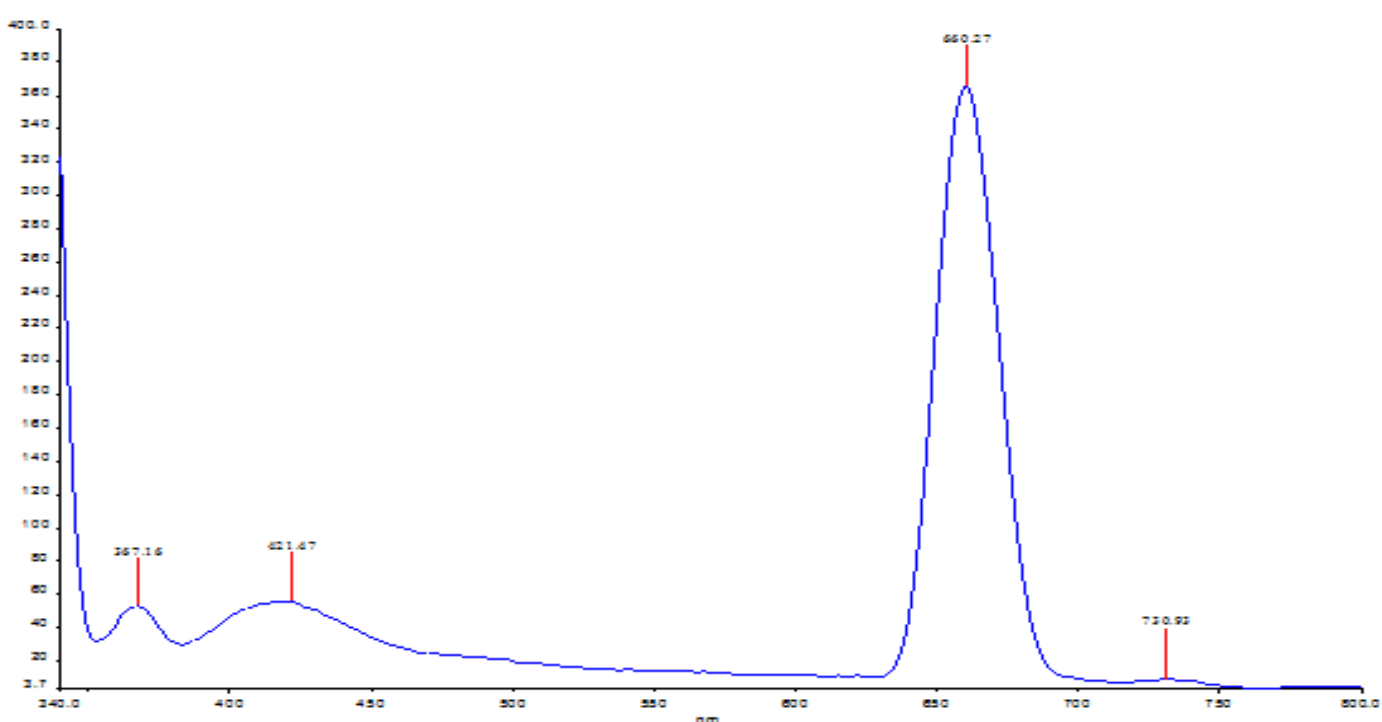

Figure 14: Electronic spectrum of Cu (II) complex

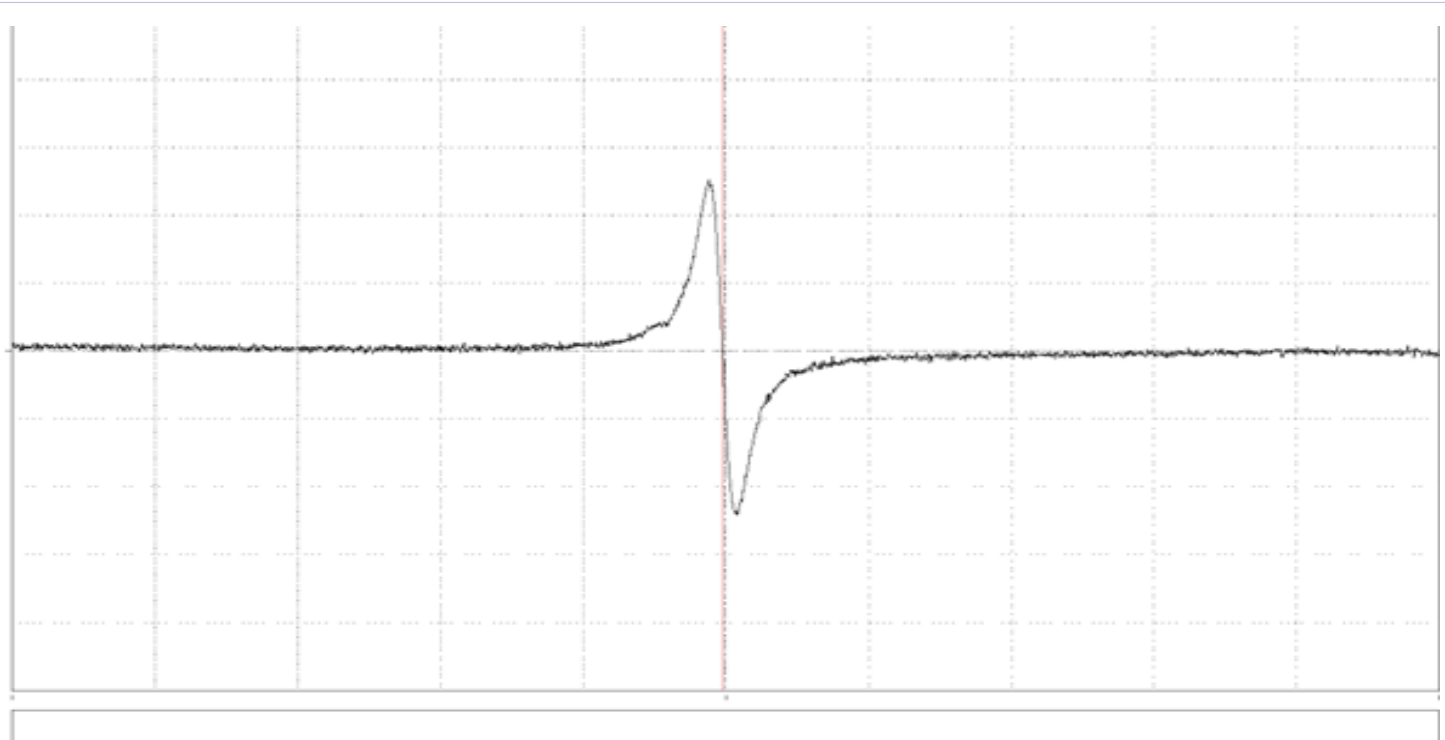

Figure 15: EPR spectrum of Cu (II) complex 


\section{Antimicrobial activity}

Antimicrobial activity was estimated as described by [18] Surface of the Mueller Hinton Agar (MHA) plates were inoculated by spreading a volume of the microbial inoculums ( 0.5 McFarland standards) over the entire agar surface. Then, a hole with a diameter of 6 to $8 \mathrm{~mm}$ was punched aseptically with a sterile cork borer and a volume $(20-100 \mathrm{~mL})$ of the extract solution at desired concentration is introduced into the wells. Then, agar plates were incubated at $37^{\circ} \mathrm{C}$ for 24 hours. The antimicrobial agent diffuses in the agar medium and inhibits the growth of the microbial strain tested the zone of inhibition was measured with a measuring scale. The antimicrobial activity of the ligand and its $\mathrm{Co}(\mathrm{II}), \mathrm{Ni}(\mathrm{II})$ and $\mathrm{Cu}(\mathrm{II})$ metal complexes were assayed against (i) Gram-positive bacteria: Staphylococcus aureus, Enterococci and (ii) Gram-negative bacteria: Escherichia coli, Pseudomonas aeruginosa. The result of antimicrobial activity is summarized in (Table 3). From the data it is clear that the metal complex is effective against bacteria.

\section{Molecular docking study}

The biological importance of the synthesized ligands are assessed by performing docking studies using Auto Dock VinaPyRx software [19]. The retrieved pdb file (4s1y) is given as input in Auto Dock Vina and assigned as macromolecule that adds charges and hydrogen bonds to the atoms thus preparing the protein. Ligand preparation including the generation of various tautomers, assigning bond orders, ring conformations and stereo chemistries of the ligand were carried out. All the conformations generated were further used for docking study. A receptor grid was generated around the protein active site by selecting the active residues (His 288, Met 298, Met 329, and Met 548) and Run auto grid option. The docking calculations were performed using Run Vina and the Binding affinity was used to determine the best docked structure from the output. The predicted binding affinity is in $\mathrm{kcal} / \mathrm{mol}$. The pdb structure $4 \mathrm{~s} 1 \mathrm{y}$ [20] of human serum albumin is used for docking studies which plays a key role in increasing the growth and productivity of cells and increases overall cell health. The best docked complex selected has a binding score of -9.5 for $\mathrm{Cu}$ (II) complex which predicts a good inhibition. The pdb structure 4sy1 of human serum albumin is used for the docking studies with 2 different compounds containing the Copper and Nickel complexes. The one with best binding affinity is considered for analysis. The following table shows the binding affinity of ligand with 4 sy1.

Docking score using Auto dock Vina with the macro molecule $4 \mathrm{~s} 1 \mathrm{y}$.

The docked ligand interacts with the protein by forming three H bonds with the residues Ser192 and Glu292 with bond distances $3.33 \AA$ and $3.53 \AA ̊$ respectively (Figure 16).

Similarly Copper (II) complex also forms $3 \mathrm{H}$-bonds with the protein in residues Glu292, Gln196, Lys 199 with bond distances $3.43 \AA$, $3.09 \AA$ and $3.21 \AA$ respectively (Figure 17). Nickel (II) complex forms 2 H-bonds with Lys $195 \AA$ and Ala191 $\AA$ residue with bond distance $3.20 \AA$ and $3.35 \AA ̊$ (Figure 18).

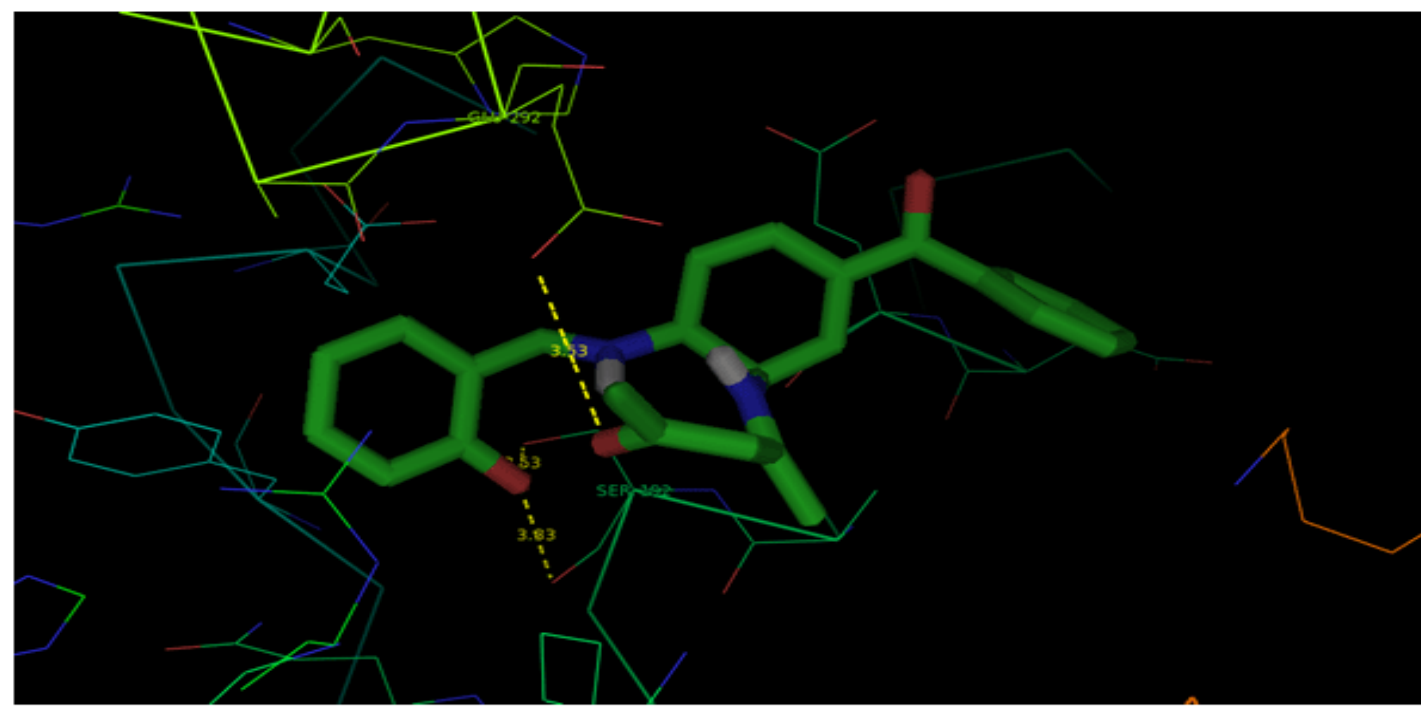

Figure 16: Ligand docked with 4s1y showing formation of hydrogen bond and distances 


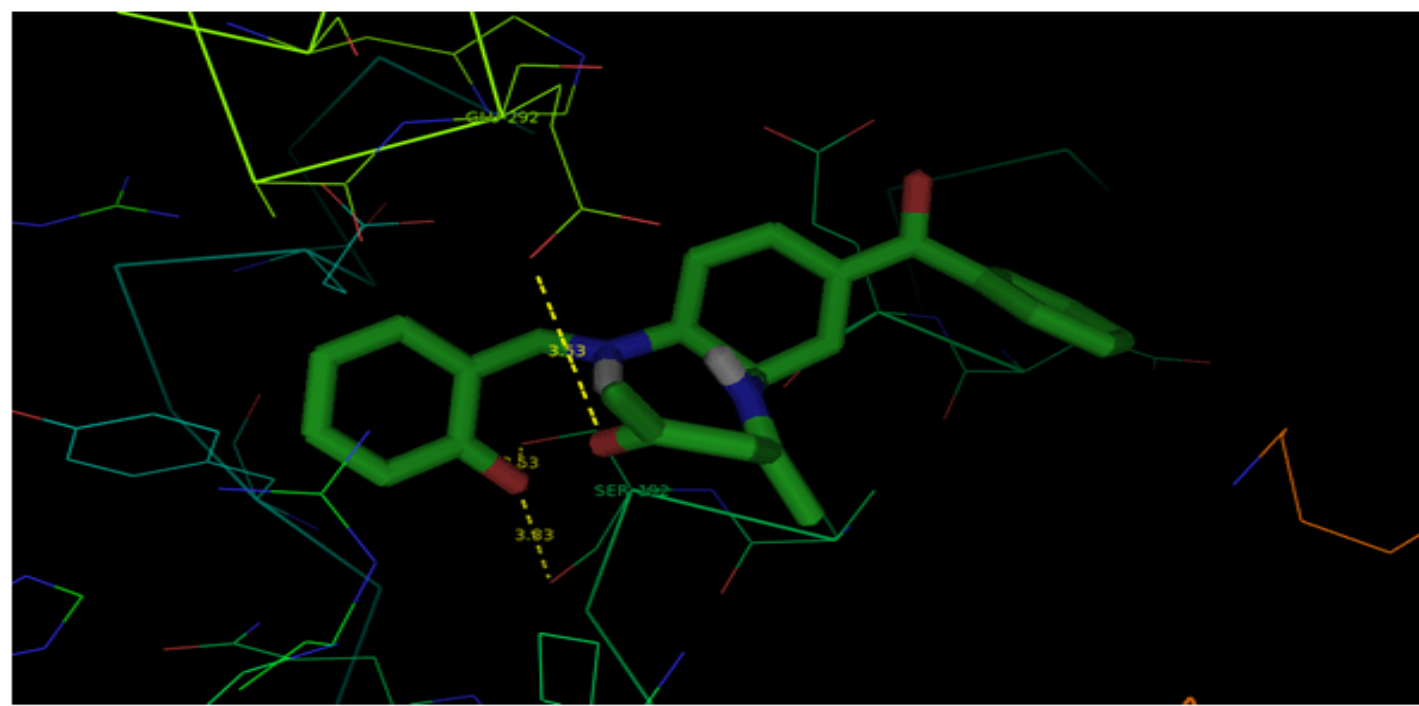

Figure 17: Copper (II) complex docked with 4s1y showing formation of hydrogen bond and distances

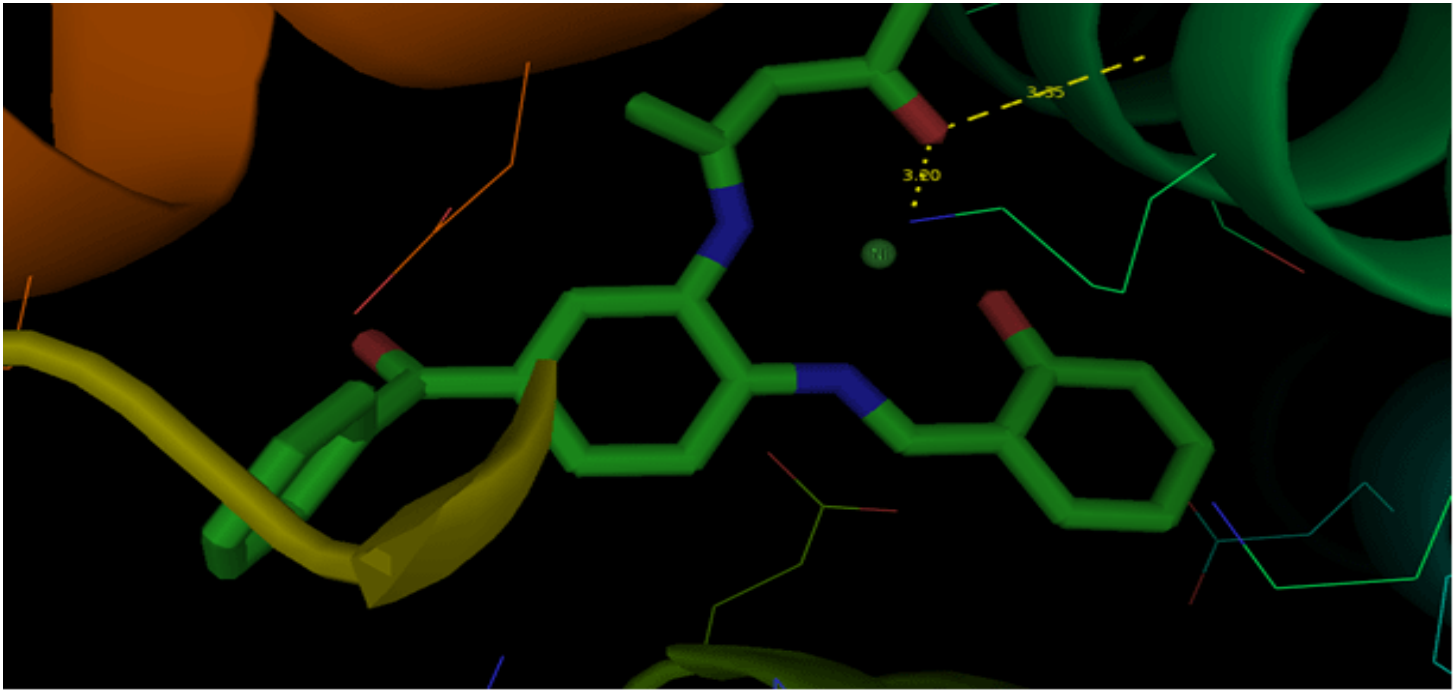

Figure 18: Nickel (II) complex docked with 4s1y showing formation of hydrogen bond and distances

\section{Conclusions}

Some new di-imino Schiff base ligands and their complexes with $\mathrm{Co}$ (II), Ni (II) and Cu (II) were synthesized and characterized. All the complexes were octahedral in nature. The binding affinity values were determined from docking studies using Auto Dock VinaPyRx software. The antimicrobial activity of the ligand and its metal complexes were assayed against Gram-positive and Gram-negative bacteria. The result of antimicrobial activity is shown that the metal complexes are effective against bacteria

\section{References}

1. Mahmud T. School Of Chemistry; University Of Manchester: Manchester. 2010:4-5.

2. RishuKatwal, H.K.a.B.K.K. AReview. Sci Revs Chem Commun. 2013;3(1):1-15.

3. Prakash A, Adhikari D. Application of Schiff bases and their metal complexes-A Review. International Journal of Chem Tech Research. 2011;3(4):1891-1896.

4. Goel P, Kumar D, Chandra S. Schiff's Base Ligands and Their Transition Metal Complexes as Antimicrobial Agents. Journal of 
Chemical, Biological and Physical Sciences. 2014;4(3):1946-1964.

5. da Silva CM, da Silva DL, Modolo LV, Alves RB, de Resende MA Martins CVB, et al. Schiff bases: A short review of their antimicrobial activities. Journal of Advanced Research. 2011;2(1):1-8.

6. Zoubi WA. Biological Activities of Schiff Bases and Their Complexes: A Review of Recent Works. International Journal of Organic Chemistry. 2013;3:73-95.

7. Azza AA AH, Wolfgang L. Synthesis, spectroscopic and biological activities studies of acyclic and macrocyclic mono and binuclear metal complexes containing a hard-soft Schiff base. Spectrochimica Acta Part A: Molecular and Biomolecular Spectroscopy. 2012;95:596609. Doi:10.1016/j.saa.2012.04.057

8. Kandil F, Chebani MK, Zoubi WA. Synthesis of Macrocyclic BisHydrazone and Their Use in Metal Cations Extraction. International Scholarly Research Network: ISRN Organic chemistry. 2012;Article ID 208284:1-8. doi:10.5402/2012/208284

9. Usharani M, Akila E, Jayaseelan P, Rajavel R. Structural Elucidation of Newly Synthesized Potentially Active Binuclear Schiff Base $\mathrm{Cu}(\mathrm{II}), \mathrm{Ni}(\mathrm{II}), \mathrm{Co}(\mathrm{II})$ and $\mathrm{Mn}(\mathrm{II})$ Complexes Using Physicochemical Methods. International journal of scientific \& Engineering Research 2013;4(7):2229-5518.

10. Raman N, Baskaran T, Selvan A, Jeyamurugan R. DNA interaction and antimicrobial studies of novel copper (II) complex having ternary Schiff base. J Iran Chem Res. 2008;1:129-139.

11. Pushpanathan V, Sureshkumar D. Template Synthesis of Zinc (II) Complexes of Nitro, Chloro, and Methyl Substituted 18-Membered Macrocycles and their Thermal, Fluorescence and Antibacterial Studies. International Journal of Inorganic and Bioinorganic Chemistry. 2013;3(2):35-43.
12. Prasad R, Thankachan PP, Thomas MT, Pathak R. Synthesis of aryl substituted azomethine complexes of iron-, cobalt- and copper(II). Journal of the Indian Chemical Society. 2001;78(1):28-31.

13. Kumar NRS, Nethiji M, Patil KC. Preparation, characterization, spectral and thermal analyses of (N2H5)2MCl4 $2 \mathrm{H} 2 \mathrm{O}(\mathrm{M}=\mathrm{Fe}$, $\mathrm{Co}, \mathrm{Ni}$ and $\mathrm{Cu}$ ); crystal structure of the iron complex. Polyhedron. 1991;10(3):365-371.

14. Patil SA, Unki SN, Kulkarni AD, Naik VH, Badami PS. Co (II), Ni (II) and $\mathrm{Cu}$ (II) complexes with coumarin-8-yl Schiff-bases: Spectroscopic, in vitro antimicrobial, DNA cleavage and fluorescence studies. Spectrochimica Acta Part A: Molecular and Biomolecular Spectroscopy. 2011;79(5):1128-1136.

15. Lakshmi B, Avaji PG, Shivananda KN, Nagella P, Manohar SH, Mahendra KN. Synthesis, spectral characterization and in vitro microbiological evaluation of novel glyoxal, biacetyl and benzil bishydrazone macrocyclic Schiff bases and their Co(II), Ni(II) and Cu(II) complexes. Polyhedron. 2011;30(9)1507-1515.

16. Palaniandavar M, Natarajan C. Aust J Chem. 1980;33:737.

17. Khulbe RC, Bhoom YK, singh RP. J Chem Soc. 1981;50:840.

18. Balouiri M, Sadiki M, Ibnsouda SK. Methods for in Vitro Evaluating Antimicrobial Activity: A Review. Journal of Pharmaceutical Analysis. 2016;6:71-79.

19. Trott O, Olson AJ. AutoDock Vina: improving the speed and accuracy of docking with a new scoring function, efficient optimization and multithreading. J Comput Chem. 2010;31(2):455-461. Doi:10.1002/ jcc. 21334

20. Ferraro G, Massai L, Messori L, Merlino A. Cisplatin binding to human serum albumin: a structural study. Chem Commun (Camb). 2015;51(46):9436-9439. 